\title{
PUBLIC-PRIVATE INTERFACE
}

\section{Science-Business eXchange}

\section{Evotec's growing Ivy}

\section{By Kai-Jye Lou, Staff Writer}

Evotec AG is double dipping into the Ivy League, this time partnering with Yale University to move early stage research from the university's labs into late preclinical and INDready assets for third parties to license. The Yale collaboration is upstream of the biotech's 2011 deal with Harvard University because the projects are not predefined.

Evotec and Yale will jointly assess and develop assays, screens, models, compounds and targets for projects that are taken up under the collaboration. The partners initially will focus on metabolic, CNS, immunology and cancer projects, although they have not yet selected any programs.

"Evotec is engaged in the development and validation of new targets and technologies, and we have the assay systems and infrastructure needed to bring the innovative science at Yale forward into industry-scale drug development programs," said Evotec CSO Cord Dohrmann. “Thus far, wevve established a framework agreement that gives sufficient comfort to both parties to take forward early stage research projects. What we need to do now to move forward is to have more in-depth discussions with principal investigators at Yale on potential project ideas."

The biotech will have an option to license any technologies developed under the deal. Costs will be shared by Evotec and Yale, as well as revenues from any deals with third parties. Details were not disclosed.

\section{Going earlier}

Dohrmann said Evotec hopes to repeat the success it had with its March 2011 collaboration with Harvard to discover diabetes therapies targeting $\beta$ cell regeneration.

The resulting portfolio of molecules and biologics from the Harvard deal were picked up by the Janssen Pharmaceuticals Inc. unit of Johnson \& Johnson in July 2012 for an $\$ 8$ million upfront payment to the partners and potential milestone payments of up to $\$ 300$ million per product plus royalties. ${ }^{1}$

"We have the assay systems
and infrastructure needed
to bring the innovative
science at Yale forward
into industry-scale drug
development programs."
-Cord Dohrmann, Evotec AG

He added that Evotec and Yale will still be involved in the R\&D process after an asset is picked up by a pharma partner. "We're not just taking technologies out of academic labs and moving them over the fence to pharma," he told SciBX.

"We think this collaboration will increase the odds of our technologies being developed and commercialized," added Christopher Unsworth, associate director at the Office of Cooperative Research at Yale. "Evotec has an established record of doing partnerships with pharma and in putting together asset packages that could be partnered."

Evotec has ongoing drug discovery and development deals with over 10 pharmas. With the Yale deal, the biotech now has at least four collaborations with universities and research organizations (see Table 1, "Evotec's partnerships with universities and research organizations").

In its earnings report for the first 9 months of 2012, Evotec reported

Table 1. Evotec's partnerships with universities and research organizations. Evotec AG's Open Innovation Alliance with Yale University is among the few drug discovery and development partnerships it has with a university or research organization. The biotech already has ongoing partnerships with more than 10 pharmas.

Source: BioCentury Archives

\begin{tabular}{|c|c|c|c|c|}
\hline Partners & Disease area & Description & Status & Announced \\
\hline Yale University & Various & $\begin{array}{l}\text { Open Innovation Alliance to jointly assess and develop } \\
\text { technologies from the university into late preclinical and } \\
\text { IND-ready assets that could be licensed to pharma }\end{array}$ & Project selection & January 2013 \\
\hline $\begin{array}{l}\text { Brigham and Women's } \\
\text { Hospital/Harvard University }\end{array}$ & $\begin{array}{l}\text { Renal damage/ } \\
\text { renal disease }\end{array}$ & $\begin{array}{l}\text { CureNephron collaboration to jointly discover biomarkers } \\
\text { implicated in kidney damage and develop therapies against } \\
\text { kidney disease }\end{array}$ & Preclinical testing & January 2012 \\
\hline $\begin{array}{l}\text { Harvard/Howard Hughes } \\
\text { Medical Institute/Johnson \& } \\
\text { Johnson (NYSE:JNJ) }\end{array}$ & Diabetes & $\begin{array}{l}\text { CureBeta collaboration to jointly discover and develop } \\
\text { therapies that target pancreatic } \beta \text { cell regeneration }\end{array}$ & $\begin{array}{l}\text { Preclinical testing; } \\
\text { portfolio of small } \\
\text { molecules and biologics } \\
\text { licensed to J\&J's Janssen } \\
\text { Pharmaceuticals Inc. } \\
\text { unit }\end{array}$ & $\begin{array}{l}\text { March } 2011 \\
\text { (Harvard/HHMI); } \\
\text { July } 2012 \text { (J\&J) }\end{array}$ \\
\hline CHDI Foundation Inc. & $\begin{array}{l}\text { Huntington's } \\
\text { disease }\end{array}$ & $\begin{array}{l}\text { Strategic partnership to provide the foundation with } \\
\text { medicinal chemistry, assay development, screening and } \\
\text { library synthesis services }\end{array}$ & Not applicable & $\begin{array}{l}\text { August 2006; third } \\
\text { deal extension in } \\
\text { October } 2012\end{array}$ \\
\hline
\end{tabular}




\section{ANALYSIS}

$€ 16$ million (\$20.4 million) in milestone, upfront and license payments from its partnerships.

"From the university side, we've been seeing in recent years that it is becoming more and more difficult to partner university-stage research assets with pharma and biotech as they've become more risk averse," Unsworth told SciBX. "The perspective from pharma is that university technologies are interesting, but those that you would actually be comfortable bringing in through the door are few and far between. The collaboration with Evotec puts in place a mechanism whereby our faculty will be able to rapidly transition a concept in the lab into an early stage therapeutic package that's ready for partnering."

\section{Moving past the startup}

Evotec and Yale think their model will be more efficient than forming new companies to commercialize technologies in academia and will reduce the time that technologies spend in early stage development.

"When forming companies around new technologies, the time spent developing the technology itself often ends up being very little relative to the time spent on other necessary activities," Dohrmann said. "For example, it usually takes at least a year to just raise an initial round of funding, and another year to get the labs and the right people in place. And at this point, the new company will usually need to seek an additional round of financing. This process of getting an industry-scale drug development program in place can take three to five years."
He said Evotec's partnership model shortcuts all of this.

"Nothing has to be built, and projects could be pursued and developed in a very efficient manner from day one," he said. "And from day one, we could already be looking for potential partners from biotech and pharma that could complement our efforts to take the early stage technology into the clinic."

Unsworth said the immediate goals of the partnership are to start the dialog between Evotec and Yale scientists and to get projects up and running. Success will be measured by the number of projects that are started, he said.

"Of course, the key measure of success for the collaboration itself is going to be whether we are generating assets that are being licensed by pharma," Unsworth told SciBX.

Lou, K.-J. SciBX 6(4); doi:10.1038/scibx.2013.80

Published online Jan. 31, 2013

\section{REFERENCES}

1. McCallister, E. BioCentury 20(31), A9-A10; July 30, 2012

COMPANIES AND INSTITUTIONS MENTIONED

Evotec AG (Xetra:EVT), Hamburg, Germany

Harvard University, Cambridge, Mass.

Johnson \& Johnson (NYSE:JNJ), New Brunswick, N.J.

Yale University, New Haven, Conn. 